\title{
Editors publishing in their own journals - a systematic review of prevalence and a discussion of normative aspects
}

\author{
Gert Helgesson $^{1 *}$, Igor Radun ${ }^{2,3}$, Jenni Radun ${ }^{4}$, Gustav Nilsonne ${ }^{5,6,7}$ \\ ${ }^{1}$ Stockholm Centre for Healthcare Ethics (CHE), Department of Learning, Informatics, \\ Management and Ethics, Karolinska Institutet, Stockholm, Sweden \\ gert.helgesson@ki.se
}

ORCID: 0000-0002-0075-0165

${ }^{2}$ Department of Psychology and Logopedics, Faculty of Medicine, University of Helsinki, Helsinki, Finland

${ }^{3}$ Department of Psychology, Stress Research Institute, Stockholm University, Stockholm, Sweden

igor.radun@helsinki.fi

ORCID: 0000-0002-2932-2383

${ }^{4}$ Turku University of Applied Sciences, Turku, Finland jenni.radun@turkuamk.fi

ORCID: 0000-0003-3269-2999

${ }^{5}$ Department of Clinical Neuroscience, Karolinska Institutet

${ }^{6}$ Department of Psychology, Stockholm University

${ }^{7}$ QUEST Center, Berlin Institute of Health at Charité - Universitätsmedizin Berlin gustav.nilsonne@ki.se

ORCID: 0000-0001-5273-0150 


\section{ABSTRACT}

Journal editors are the main gatekeepers in scientific publishing. Yet there is a concern that they may receive preferential treatment when submitting manuscripts to their own journals. The prevalence of such self-publishing is not known, nor the consequences for reliability and trustworthiness of published research. This study aimed to systematically review the literature on the prevalence of editors publishing in their own journals and to conduct a normative ethical analysis of this practice. A systematic review was performed using the following databases: Medline, PsycInfo, Scopus, and Web of Science. Articles that provided primary data about editors publishing in own journals were included. We identified 15 studies meeting inclusion criteria. There was large variability of self-publishing across fields, journals, and editors, ranging from those who never published in their own journal to those publishing extensively in their own

journal. Many studies suffered from serious methodological limitations. Nevertheless, our results show that there are settings where levels of self-publication are very high. We recommend that editors-in-chief and associate editors who have considerable power in journals refrain from publishing research articles in their own journals. Journals should have clear processes in place about treatment of articles submitted by editorial board members.

\section{Key points:}

- There is concern that editors submitting papers to their own journals may receive preferential treatment

- Our results show that the prevalence of editors publishing in their own journals varies greatly among journals

- Our systematic review does not show that compromised review practices benefitting editors publishing in their own journal are widespread

- It is important that journal guidelines include clear information about the handling procedure for submissions authored by editors

- Overall, it is preferable that at least editors-in-chief strive to avoid publishing research papers in their own journals

Keywords: authorship; bias; conflict of interest; editors; editorial boards; publication ethics 


\section{INTRODUCTION}

Publication in scientific journals is a primary mode of research communication as well as a currency of merit for individual scientists. Therefore, mechanisms to determine what gets published have major impact on the quality and trustworthiness of the scientific literature as a whole and on individual scientists' careers.

Editors of scientific journals are the main gatekeepers in scientific publishing. Typically, a decision to accept a research article for publication is preceded by peer review, which is intended to ensure that work of low quality is less likely to be published (although the efficacy of peer review for this purpose has been debated (e.g. Smith, 2006). However, conflicts of interest may challenge the impartiality of editorial handling (Radun, in press). Since most editors are active researchers, they not only evaluate others' academic work, but produce their own (Bedeian et al 2009; Pardeck \& Meinert 1999; Zdeněk \& Lososova 2018). One potential conflict of interest arises when an author of a research article at the same time is an editor of the journal. Such a conflict of interest may exist even if the manuscript is handled by another editor of the journal.

Some journals publish original work contributed by their own editors, while others do not (Graf et al 2007). There have been remarkable examples of editors with a massive output of research papers in their own journals. In an extreme case from theoretical physics, an editor is claimed to have published nearly 60 papers in his own journal during one year (Schiermeier 2008).

Risk of bias, favoritism, and conflicts of interest are central themes brought up by critics regarding editors publishing in their own journals (Bošnjak et al. 2011). Favorable treatment may include different facets such as selection of reviewers known to be friendly, a higher likelihood of acceptance, and faster handling. For instance, Scanff et al. (2021) reported that in a set of journals $(n=98)$ with a high proportion of papers from particularly prolific authors, "the most prolific author was part of the editorial board in 60 cases $(61 \%)$, among whom 25 (26\% of the 98) were editors-in-chief", and that papers by these authors were more likely to be accepted for publication within 3 weeks of their submission. Very short lag times between submission and publication were observed for some papers authored by journal editors, calling into question whether these papers were peer reviewed in any meaningful sense. 
Publication by editors in their own journals nevertheless finds its defenders, in several guidelines and journals and in science-related social media (see discussion below). In order to judge the potential severity of problems relating to editors publishing in their own journals, knowledge about the prevalence of this practice is essential.

This study aimed firstly to investigate the prevalence of editors publishing in their own journals by means of a systematic review, and secondly to discuss normative issues relating to editors publishing in their own journals.

In what follows, we first describe the empirical methods used and the results from the literature survey of empirical studies about editors publishing in their own journals. Then we present recommendations of some well-established guidelines on the matter and summarize arguments identified in the literature and in social media. Thereafter, we provide our own analysis of arguments in favor of and against editors publishing in their own journals, as well as regarding what restrictions and regulations that need to be in place for such practice to be defensible.

\section{METHODS}

A systematic search of the peer-reviewed literature was performed on 30 December 2020. The following databases were used: Medline, PsycInfo, Scopus, and Web of Science. Articles that provided primary data about editors publishing in own journal were included. The search was

performed jointly by one researcher (IR) and an information specialist at the Helsinki University Library (for the full search strategy, see Appendix I). Duplicates were removed by two methods: automatic removal of duplicates in EndNote and manual removal. Both methods produced an almost identical result. Two researchers (IR \& JR) independently screened titles and abstracts, resulting in 44 relevant articles. After full text screening, the final sample included 15 articles (for the Prisma flow chart, see Appendix II). The same two researchers then independently read the selected articles, discussed each study, and extracted information on (a) sampling frame: journals, editors, years, and types of publication; and (b) main findings - and agreed upon the final extracted data. Methodological limitations and considerations were noted in a separate column. None of the 15 papers has been retracted according to the publishers' websites (October 24, 2021). The full list of search results is available on https://osf.io/dtcsp/. 
In the normative part of this study, we have included argumentation from the excluded 29 articles which were nevertheless read in full. However, this extraction was not done in a systematic manner. In addition to this material, argumentation found in social media discussing these practices was also included. These sources have not been searched systematically.

\section{RESULTS AND DISCUSSION OF SYSTEMATIC REVIEW}

Table 1 lists included studies, their extracted information, and our comments on their methodology. Out of the 15 studies, 10 were focused in scope on a particular scientific field or subfield (e.g. finance, public administration, surgery, urology), while 5 were focused in scope to a particular country or set of countries.

The prevalence of self-publishing by editors was highly variable between the included papers, ranging from zero to publishing extensively in their own journal, with some editors publishing only in journals where they are editors. In some journals the majority of the articles have been contributed by their own editors (Rösing et al., 2014).

\section{Methodological considerations}

There was large variability in employed methods and rigor limiting interpretations. First, not all studies carefully considered when editors took on their role as editors. If we are to learn from studies whether or not editors receive preferable treatment in their own journals, then it is crucial to know exactly when they took on that role. One promising approach would be to compare editors' number and proportion of publications in their own journal between pre-editorial and editorial periods (and, perhaps, between editorial and post-editorial periods for still active researchers). In this respect, Mani et al. (2013) is a unique study.

Another methodological issue relates to the type of publications included in analyses. In some studies (e.g., Goudra et al., 2018; Hardin et al., 2008) all types of articles were included, also editorials. However, it blurs the picture if editorials are counted the same as original papers and systematic reviews in the analysis. Editorials are expected to be written by editors, and to reflect their views in the editorial role. If these article categories are not disaggregated, then no clear conclusions can be drawn regarding whether or not editors are favored when it comes to having substantial research articles accepted. 
A final methodological issue is that in many studies all editors were grouped together without acknowledging differences in power between editors in chief, associate editors, and editorial board members. This is perhaps the key issue if we consider favoritism as one of the main arguments against self-publishing. For example, if a journal has a large number of editorial board members, it is possible that editors in chief/associate editors who primarily deal with submissions do not even know whether a given author is in the editorial board of their journal. On the other hand, everyone working with the journal knows the editor in chief and associate editors who have the real power in the journal. Here the problem of preferable treatment is a real issue. For example, an associate editor who works closely with the editor in chief might not reject their submission regardless of its quality.

\section{Interpretation and conclusion}

The papers we have reviewed reveal a complex set of motivations for editors to publish in their own journals. Not only can editors potentially benefit from using their position to gain publications as a currency of merit; also journals can benefit from well-known scientists in editorial roles submitting important work to increase the journal's visibility, quality, and citation rates (Dose \& Huber, 2009; Goudra et al. 2018). Thus, there may exist an interplay between editors and journals in the prestige economy of science, where reputation and influence can be exchanged for mutual benefit (Kwiek, 2020).

Our systematic literature review shows that knowledge about publication practices of journal editors is still limited. The material identified in the survey is quite meager, and the methods used have considerable limitations. More needs to be learnt about editors' practices of publishing in their own journals.

\section{NORMATIVE ANALYSIS}

\section{Ethical guidelines on editors publishing in their own journals}

Following this presentation and discussion of our systematic literature review of editors' practices of publishing in their own journals, we turn to some highly influential organizations to see what they say on the matter: the Council of Science Editors, the International Committee of Medical Journal Editors (ICMJE), the Committee On Publication Ethics (COPE), and the World Association of Medical Editors (WAME). 
The Council of Science Editors (CSE) write the following on editors' roles and responsibilities in their White paper on publication ethics, under "Conflicts of interest":

\begin{abstract}
Also, editors should submit their own manuscripts to the journal only if full masking of the process can be ensured (e.g., anonymity of the peer reviewers and lack of access to records of their own manuscript). Journals should have a procedure in place to guide the handling of submissions by editors, associate editors, editorial board members, and colleagues/students of any of these to allow for peer review and decision making that avoids any conflict of interest. Editorials and/or opinion pieces are an exception to this rule.
\end{abstract}

Two messages are implicit in this brief statement: first, that CSE does not advise against editors publishing in their own journals and, second, that CSE recommends that they should only do so if listed requirements of an unbiased evaluation procedure can be fulfilled.

The International Committee of Medical Journal Editors (ICMJE) write in their Recommendations for the conduct, reporting, editing, and publication of scholarly work in medical journals that

\begin{abstract}
"[e]ditors who make final decisions about manuscripts should recuse themselves from editorial decisions if they have relationships or activities that pose potential conflicts related to articles under consideration. [...] Journals should take extra precautions and have a stated policy for evaluation of manuscripts submitted by individuals involved in editorial decisions."
\end{abstract}

This is consistent with the CSE position but less far-reaching. Apart from these remarks, the Recommendations refer to COPE. The Committee On Publication Ethics (COPE) explicitly asks whether or not editors can publish in their own journal in their document A short guide to ethical editing for new editors and provides the following answer:

While you should not be denied the ability to publish in your own journal, you must take extra precautions not to exploit your position or to create an impression of impropriety. Your journal must have a procedure for handling submissions from editors or members of the editorial board that will ensure that the peer review is handled independently of the author/editor. We also recommend that you describe the process in a commentary or similar note once the paper is published. 
In other words, the COPE message here is: you can publish in your own journal, but do it with caution and use a procedure with safeguards against preferential treatment that you should openly describe. COPE does not bring the topic up in their Best practice guideline for journal editors, except in a response to a question:

The issue here basically revolves around whether it is acceptable for editors to publish their own work in their journals; if it is, then the review process must be made as transparent and rigorous as possible.

COPE adds that it would be suitable for the journal to add a short statement in connection with the publication informing about the procedures undertaken in the review of the paper. It is clear that there are occasions when COPE finds it acceptable for editors to publish in their own journals, namely (as they put it) "where the choice of journals is limited". It remains unclear if this is understood to be the only permissible exception, and how limited the choice of journals has to be for submission by editors to their own journal to be permissible. In the absence of detailed clarification, it nevertheless seems clear that COPE expresses the view that editors' sending manuscripts to their own journal should be the exception. Such a restriction is not mentioned in the COPE guidelines for new editors quoted above.

The World Association of Medical Editors (WAME) states, in their 2009 document Conflict of interest in peer-reviewed medical journals:

When editors submit their own work to their journal, a colleague in the editorial office should manage the manuscript and the editor/author should recuse himself or herself from discussion and decisions about it.

Hence, on WAME's view, a careful procedure when editors publish in their own journal involves a strict hands-off approach from the submitting editor.

To sum up, the attitude manifested in some of the leading publication ethics guidelines is that editors may publish in their own journal, but there must be a procedure in place to show that they are not given any undue advantages in the review process. And it may be preferable that they do not submit articles to their own journal when there are adequate alternatives. 


\section{Arguments from the literature}

Hamilton et al. (2020) asked 322 editors of journals in ecology, economics, medicine, physics, and psychology, among other things, about their views on publishing in their own journal. The majority (79\%) responded that they found it acceptable under certain conditions (such as independent editing and reviewing) while a minority stated that this would not be acceptable for any editor (13\%) or for the lead editor (8\%). Of main interest in what follows are the arguments in favor of either position regarding editors publishing in their own journal. The literature on this specific topic is so far limited. We here present the arguments we have found, starting with criticism, followed by defense of the practice and specification of conditions that need to be fulfilled to make such practice defensible.

\section{Arguments against editors publishing in their own journals}

One argument against the practice concerns undue influence over the evaluation of submitted manuscripts. The editor's own manuscript may be more likely to be published, even if it has quality issues. As phrased by Richard Smith, editor of BMJ: "The argument against is that they [editors] will have undue influence over the process and possibly be able to get inferior work published" (Smith 2002). Rosenblum (2020) takes the reasoning further by arguing that "knowingly [...] bypassing the peer-review process to self-publish constitutes editorial misconduct". Even if editors do not pressure journal colleagues to accept their work, or decide on their own about their own manuscript, favoritism may still lead to easier acceptance of submitted papers (Luty et al. 2009). Also reviewers may contribute to this favoritism in the sense that they may be less inclined to criticize and value the manuscript on its merits alone if the review is not blinded (Sen-Crowe et al., 2020). Even if none of this happens, the mere possibility that editors submitting manuscripts to their own journal receive a more favorable treatment than other researchers may be harmful to the perception of both journal and editor (Walters 2015).

\section{Arguments in favor of editors publishing in their own journals}

Some of the arguments in defense of editors publishing in their own journal are general and apply equally to all kinds of journals, while some arguments are more specific and apply to more specialized journals or small research fields only. General arguments defending a practice where editors publish in their own journals claim that 
- $\quad$ it would be unfair to editors not to have the opportunity to publish in their journal (Hamilton, 2020; Smith, 2002).

- $\quad$ it would risk deterring potential editors if they would not be able to publish in the journal for which they became editor, which threatens to lead to less competent persons taking on the job (Rosenblum, 2020; Hamilton, 2020).

- such restrictions would also have negative, and unfair, effects on collaborators of researching editors, since their options are also affected for their joint papers (Hoey, 1999; Hamilton, 2020).

Some arguments particularly concern specialized journals or small research fields, such as:

- It would be bad for the readers and the field if they missed specialized content suitable mainly for a specialized journal, if editors in the field were not allowed to publish in their journal (Rosenblum 2020). It has been suggested that some original research may be of main interest to the reader of that specific journal - arguably one should try to publish where the material is most relevant (Hoey 1999; Smith 2002; Youk \& Park 2019, Zdenek \& Losova 2018).

- It would be bad for the journal to miss the opportunity to publish editors who research and who may very well have been selected as editors for their skill in the field, and whose paper is very much suited for the readership (Smith 2002; Hamilton 2020).

- It would be particularly unfair to editors if they are not able to publish in what might be the best journal, or one of the most relevant ones, in their special are of competence (Smith 2002).

As remarked by Walters (2015), it is not entirely clear what editors and editorial board members would like to do, since there is an attraction of publishing in the "right" journal, but also criticism against publishing in one for which one is editor:

It seems reasonable to assume that authors will send their papers to the journals that best match their interests, which are presumably the same journals for which they are most likely to serve as board members. At the same time, board members may avoid sending manuscripts to their own journals in order to avoid any real or perceived conflict of interest. 


\section{Proposed conditions and restrictions regarding editors publishing in their own journal}

Several voices friendly to the idea that editors publish in their own journal nevertheless express that this practice requires precautions to deal with the problems critics tend to point at.

Editors can legitimately publish a peer-reviewed article in the journal they edit as long as the manuscript undergoes peer review that is as thorough as all other manuscripts, and the member of the editorial board overseeing the peer review does his or her best to ensure that any bias in the assessment of the manuscript is minimized (Young, 2009).

One proposed precaution, also found in the guidelines discussed above, is that editors submitting manuscripts to their own journal should be excluded from all aspects of the review process, in order to guarantee an unbiased peer review-based procedure that they do not influence. This needs to be an established mechanism in place that is automatically applied whenever relevant (Hoey 1999; Graf et al. 2007; Mani et al. 2013).

It has also been suggested, also in line with the guidelines discussed above, that when such publications occur, there should be a short statement in the journal explaining the process used to make the editorial decision on the paper (Graf 2007). This would include, for example, a name of the associate editor acting as the handling editor even if names of handling editors are not typically mentioned along published articles. Here is an example of such conflict-of-interest statement: "Both authors serve as editorial assistant and editor, respectively, of Cognitive Development. Neither author was involved in the editorial process for the manuscript and appropriate steps were taken to ensure that both authors were blind to the review process" (Caporaso \& Marcovitch, 2021).

Some authors note that measures to promote and protect an adequate review process also in the case of editors publishing in their own journal "cannot absolutely prevent all editorial favoritism", but they are still meaningful since clear communication to the scientific community of a stable procedure for handling this type of situations "might help to maintain and improve journal reputation" (Mani et al., 2013).

\section{Arguments advanced in social media}

Arguments we have identified in social media both support and criticize that editors publish in their own journals. In summary, counter arguments say that the evaluation of the papers can be 
questioned, and that such situations should be avoided, especially when papers may or may not be found good enough and favoritism therefore might tip the balance. It has also been pointed out that the practice of editors publishing in their own journal might reflect negatively both on themselves and on their journals. Publishing in one's own journal might suggest that one does not dare to face open competition and hopes to be given advantages in the review process; for the journal, its high standards might be questioned by inviting the doubt of due procedure when they accept papers from their own editors. Those defending editors publishing in their own journals particularly stress that this ought not be questioned for high-quality papers, especially for editors with a strong publication track record. Others say it is generally acceptable, on the condition that the journal's review process maintains its integrity. Some suggest special procedures to guarantee this, like a panel of reviewers to make what is otherwise typical editorial decisions. Another kind of defense for editors publishing in their own journal on social media is that sometimes there are no equally good journal alternatives, either because of the unique fit between the kind of paper and the focus of the journal or because the intended readers strongly focus on the concerned journal. In such cases, the argument goes, it is not reasonable to ask of the editor to publish elsewhere.

All in all, these arguments very much reflect the arguments found in the literature, although they also include many personal experiences and calling out 'bad' practices of particular journals and editors.

\section{Analysis and discussion of arguments}

Summarizing the arguments favoring editors publishing in their own journals, they mainly point to the fair opportunity for editors to have access, like everyone else, to their journal as a possible place to publish papers. Against this, the main counter arguments relate to conflicts of interest and the risk that the submitted papers from editors undergo a biased process before getting accepted - in other words, that they get preferential (hence unfair) treatment. Scientific journals are generally assumed to verify and improve the quality of submitted manuscripts through editorial and peer review, but there is a risk that work by the journal's own editor would be favoritized and that editorial and peer review would be less stringent, in a manner not transparent to readers. Preferential treatment could also include e.g. faster handling of the submission. It is 
worth stressing that the risks identified are probably much higher in relation to editors-in-chief compared to editorial assistants and members of the editorial board.

Since the weightiest arguments against letting editors publish in their own journals are that there is a risk that they will be treated favorably, or will be suspected to be treated favorably regardless of whether or not that actually happens, a relevant question to ask is if these risks can be mitigated. In fact, there are several mechanisms that could potentially mitigate these risks:

- Transparency in the review process allows readers to inspect and appraise the process. Thus, interested readers would be able to form their own opinion about the stringency of review.

- A preset "protocol" for such occasions should be available in the journal's information to readers and potential authors, and should be applied to each such case.

- Editors submitting to their own journals should be entirely excluded from any formal influence over the decision-making regarding their own papers.

- The interaction in relation to the paper should also be such that it minimizes informal influence on the handling of the paper.

- Editors and reviewers with a perceived conflict of interest should be left out of the process of evaluation. An editor without such conflict of interest (if such exist) should initiate the protocol.

- To guarantee as far as possible that the assessment of the paper is not influenced by knowledge of who is assessed, evaluation and acceptance/rejection decisions would need to be made by persons who do not know the identities of the authors of the paper, i.e., peer reviewers and remaining journal editors alike. This is feasible in relation to peer review, unless the research field is too small to realistically keep the authors secret, and unless the journal's peer review practice is such that hidden identities would deviate from standard procedure and therefore potentially signal what is at stake. Anonymity at an editorial board level may be difficult to achieve if decisions remain in the editorial group normally handling manuscript decisions, not least unless there are other procedural reasons for stepping away from the decision regarding a particular manuscript with reference to conflicts of interest. 
A radically different approach to the one pointed out above, concerning editors-in-chief, would be to let the editor assume full responsibility and publish the paper without review. This makes very clear who is responsible for the content and the decision to publish. On the other hand, the lack of peer review may be perceived as a failure to gain canonization into the scientific literature. Also, this is not an acceptable solution for those thinking that the main disadvantage with letting editors publish in their own journal is that some may add to their publication merits by potentially facing a lower entry bar than the rest.

None of these solutions provide a fully feasible and effective strategy for mitigation, and readers may still suspect favoritism. Since downsides remain, we recommend that editors-inchief and perhaps associate editors do not publish original scientific work in their own journal. The cost of not permitting editors-in-chief and associate editors to publish research articles in their own journals will be minimal for the editors themselves and for the research field when equivalent journals are available for the editors. In cases where a journal is uniquely attractive for a certain kind of research content or with reference to a certain community of readers, the decision is more delicate. The benefit-to-cost ratio of a submission ban may also be different for associate editors compared to editors in chief, where the former sacrifice as much but gain less in form of prestige. This is even more true for editorial board members.

\section{CONCLUDING REMARKS}

According to our findings, the prevalence of editors publishing in their own journals varies greatly among journals. However, except for some clear cases, it is difficult to conclude that compromised peer review for the benefit of editors publishing in their own journal is widespread and therefore would represent a serious threat to the scholarly community.

Nevertheless, risks of bias, or perceived bias, in appraisal of submitted manuscripts should and can be reduced by strict standards for treating papers submitted by editors. Since the risk cannot be eliminated entirely, the cost of maintaining a practice where editors are allowed to publish in their own journal, in terms of reliability and trust, will then have to be weighed against the loss of not permitting this. For exceptions, a strong argument is needed relating to the specific case or circumstances. What to do depends on exactly what is in the balance. In any case, it is of utmost importance that the journal's guidelines include clear information about the procedure planned for submissions authored by editors. In conclusion, given the evidence of 
previous misuse, and suspicion thereof, it seems preferable that at least editors-in-chief strive to avoid publishing research papers in their own journals.

\section{FUNDING AND CONFLICTS OF INTEREST}

This study received no specific funding. IR, who is a member of editorial board of journal Transportation Research Part F: Psychology and Behaviour, humbly reports he had published three research papers (first author in all of them) in the journal during six-year period before he took the role in this journal in 2015 and six papers (first author in five of them) during six years while serving as a member of editorial board. Other authors report no conflicts of interest.

\section{AUTHORS' CONTRIBUTIONS}

Conceptualization: G.H., G.N., and I.R.

Systematic review: I.R. and J.R.

Writing of original draft: G.H.

Writing: review and editing: all authors.

\section{ACKNOWLEDGMENTS}

The authors thank information specialist Tiina Heino for her help with the literature search. 


\section{REFERENCES}

Bedeian, A. G., Van Fleet, D. D., \& Hyman, H. H. (2009). Scientific achievement and editorial board membership. Organizational Research Methods, 12(2), 211-238.

doi:10.1177/1094428107309312

Bošnjak, L., Puljak, L., Vukojević, K., \& Marušić, A. (2011). Analysis of a number and type of publications that editors publish in their own journals: Case study of scholarly journals in Croatia. Scientometrics, 86(1), 227-233. doi:10.1007/s11192-010-0207-7

Caporaso, J. S., \& Marcovitch, S. (2021). The effect of taxing situations on preschool children's responses to peer conflict. Cognitive Development, 57(6), 100989.

doi:10.1016/j.cogdev.2020.100989

Committee On Publication Ethics (COPE). A short guide to ethical editing for new editors. Retrieved 9 November 2021, from

http://publicationethics.org/files/short\%20guide\%20to\%20ethical\%20editing\%20for\%20new\%2 0editors.pdf

Committee On Publication Ethics (COPE). Best practice guideline for journal editors. Retrieved 9 November 2021, from https://publicationethics.org/case/editor-author-own-journal

Council of Science Editors (CSE). White paper on publication ethics. Retrieved 9 November 2021, from https://www.councilscienceeditors.org/resource-library/editorial-policies/whitepaper-on-publication-ethics/

Dose, V., \& Huber, M. (2009). Quo vadis EPL? EPL, 85(1). doi:10.1209/0295-5075/85/10000

Goudra, B., Gouda, D., Gouda, G., Singh, A., Balu, A., \& Gouda, P. (2018). Possible bias in the publication trends of high impact factor anesthesiology and gastroenterology journals - An analysis of 5 years' data. Albang Maqalat Wa Abhat Fi Altahdir Waalinas, 12(3), 611-617. doi:10.4103/aer.AER_116_18

Graf C, Wager E, Bowman A, Fiack S, Scott-Lichter D, \& Robinson A. (2007). Best practice guidelines on publication ethics: a publisher's perspective. International Journal of Clinical Practice, 61 (Suppl 152), 1-26. doi:10.1111/j.1742-1241.2006.01230.x

Hamilton, D. G., Fraser, H., Hoekstra, R., \& Fidler, F. (2020). Journal policies and editors' opinions on peer review. eLife, 9. doi:10.7554/eLife.62529

Hardin, W. G. III, Liano, K., Chan, K. C., \& Fok, R. C. W. (2008). Finance editorial board membership and research productivity. Review of Quantitative Finance and Accounting, 31(3), 225-240. doi:10.1007/s11156-007-0067-2 
Hoey J. (1999). When editors publish in their own journals. CMAJ, 161(11):1412-1413.

International Committee of Medical Journal Editors (ICMJE). Recommendations for the conduct, reporting, editing, and publication of scholarly work in medical journals. Retrieved 9 November 2021, from http://www.icmje.org/recommendations/

Kwiek, M. (2021). The prestige economy of higher education journals: A quantitative approach. Higher Education, 81(3), 493-519. doi:10.1007/s10734-020-00553-y

Luty, J., Arokiadass, S. M., Easow, J. M., \& Anapreddy, J. R. (2009). Preferential publication of editorial board members in medical specialty journals. Journal of Medical Ethics, 35(3), 200202. doi:10.1136/jme.2008.026740

Mani, J., Makarević, J., Juengel, E., Ackermann, H., Nelson, K., Bartsch, G., . . Blaheta, R. A. (2013). I publish in I edit? - Do editorial board members of urologic journals preferentially publish their own scientific work? PLOS ONE, 8(12). doi:10.1371/journal.pone.0083709

Mazov, N. A., Gureev, V. N., \& Metelkin, D. V. (2018). Bibliometric indicators of scientific journals and editorial board members (based on the example of russian journals on earth sciences). Scientific and Technical Information Processing, 45(4), 271-281. doi:10.3103/S0147688218040123

Pardeck, J. T., \& Meinert, R. G. (1999). Scholarly achievements of the social work editorial board and consulting editors: A commentary. Research on Social Work Practice, 9(1), 86-91.

Radun, I. (in press). Nonfinancial conflict of interest in peer-review: Some notes for discussion. Accountability in Research: Policies and Quality Assurance.

Reaee-Zavareh, M. S., \& Karimi-Sari, H. (2020). How often do the iranian medical journal editors-in-chief publish in their own journals? Iranian Journal of Public Health, 49(7), 13721375. doi:10.18s502/ijph.v49i7.3592

Rosenblum, S., St Clair, R. L., Isett, K. R., \& Johnson, R. (2020). Publishing while editor: Transparency and behaviour in public administration journals. Australian Journal of Public Administration, 79(4), 407-425. doi:10.1111/1467-8500.12411

Rösing, C. K., Junges, R., \& Haas, A. N. (2014). Publication rates of editorial board members in oral health journals. Brazilian Oral Research, 28(6), 434-438. doi:10.1590/1807-3107BOR2014.vol28.0042

Scanff, A., Naudet, F., Cristea, I., Moher, D., Bishop, D. V. M., \& Locher, C. (2021). 'Nepotistic journals': a survey of biomedical journals. bioRxiv, 2021.2002.2003.429520.

doi:10.1101/2021.02.03.429520 
Schiermeier, Q. (2008). Self-publishing editor set to retire. Nature, 456(7221), 432. doi:10.1038/456432a

Sen-Crowe, B., Sutherland, M., Shir, A., Kinslow, K., Boneva, D., McKenney, M., \& Elkbuli, A. (2020). Variations in surgical peer-reviewed publications among editorial board members, associate editors and their respective journal: Towards maintaining academic integrity. Annals of Medicine and Surgery, 60, 140-145. doi:10.1016/j.amsu.2020.10.042

Shamsi-Gooshki, E., Bagheri, H., \& Salesi, M. (2020). Evaluation of Iranian medical journals from the perspective of publication ethics. Archives of Iranian Medicine, 23(10), 697-703. doi:10.34172/aim.2020.88

Smith R. Rapid response to: Making progress with competing interests. Rapid Response: Should editors publish their own original research in the journals they edit? BMJ 2002, December 18. https://www.bmj.com/rapid-response/2011/10/29/should-editors-publish-their-own-originalresearch-journals-they-edit

Smith, R. (2006). Peer review: A flawed process at the heart of science and journals. Journal of the Royal Society of Medicine, 99(4), 178-182.

https://www.ncbi.nlm.nih.gov/pmc/articles/PMC1420798/

Walters, W. H. (2015). Do editorial board members in library and information science publish disproportionately in the journals for which they serve as board members? Journal of Scholarly Publishing, 46(4), 343-354. doi:10.3138/jsp.46.4.03

World Association of Medical Editors (WAME). Conflict of interest in peer-reviewed medical journals. Retrieved 9 November 2021, from http://wame.org/conflict-of-interest-in-peerreviewed-medical-journals

Youk, S., \& Park, H. S. (2019). Where and what do they publish? Editors' and editorial board members' affiliated institutions and the citation counts of their endogenous publications in the field of communication. Scientometrics, 120(3), 1237-1260. doi:10.1007/s11192-019-03169-x

Young SN. (2009). Bias in the research literature and conflict of interest: an issue for publishers, editors, reviewers and authors, and it is not just about the money. J Psychiatry Neurosci, 34(6):412-417.

Zdeněk, R. (2018). Editorial board self-publishing rates in czech economic journals. Science and Engineering Ethics, 24(2), 669-682. doi:10.1007/s11948-017-9922-2

Zdeněk R, Lososova J. (2018). An analysis of editorial board members' publication output in agricultural economics and policy journals Scientometrics, 117, 563-578. doi:10.1007/s11192018-2881-9 
Table 1. How often editors publish in own journals

\begin{tabular}{|c|c|c|c|}
\hline Study & Sample/Methods & Main results & Comments/notes \\
\hline $\begin{array}{l}\text { Bosnjak et al., } \\
2011\end{array}$ & $\begin{array}{l}\text { Journals: } 180 \text { Croatian journals } \\
\text { (167 indexed in Croatian } \\
\text { database HRCAK \& additional } 13 \\
\text { indexed in Web of Science or } \\
\text { Scopus) } \\
\text { Editors: } 256 \text { ( } 172 \text { EiCs \& } 84 \\
\text { associate, executive, or junior } \\
\text { editors) of } 167 \text { journals and } 13 \\
\text { editors of } 13 \text { journals } \\
\text { Years: } 2005-2008 \\
\text { Publications: All types and } \\
\text { "publications relevant for official } \\
\text { requirement for academic } \\
\text { promotion" }\end{array}$ & $\begin{array}{l}256 \text { editors published } 887 \\
\text { publications in own journals; } 332 \\
\text { publications "were relevant for } \\
\text { official requirement for academic } \\
\text { promotion." } \\
\text { Regarding these relevant } \\
\text { publications: } 45 \% \text { of all editors } \\
\text { ( } \mathrm{N}=269 \text { ) did not publish in their own } \\
\text { journal; } 6.6 \% \text { published } 5 \text { or more } \\
\text { articles in their own journal. } \\
\text { Only } 2 \text { editors exclusively published } \\
\text { in own journals } \\
\text { None of the journals had "a policy on } \\
\text { the manuscript submissions by } \\
\text { journal editors;" however, one } \\
\text { journal "had a statement on the } \\
\text { restrictions of published articles from } \\
\text { authors, including editorial } \\
\text { members." }\end{array}$ & $\begin{array}{l}\text { The authors concluded that the } \\
\text { majority of editors "did not } \\
\text { misuse their own journals for } \\
\text { scientific publishing and } \\
\text { academic promotion." } \\
\text { They were, however, concerned } \\
\text { about the lack of transparency } \\
\text { regarding submissions by } \\
\text { editors. } \\
\text { It was unclear when the editors } \\
\text { were editors during the whole } 4- \\
\text { year period. } \\
\text { Some inconsistency in reporting } \\
\text { (e.g., in abstract it says that } \\
\text { there were 256 editors of } 180 \\
\text { journals; however, in the text } \\
\text { the number is 269) }\end{array}$ \\
\hline $\begin{array}{l}\text { Goudra et al., } \\
2018\end{array}$ & $\begin{array}{l}\text { Journals: Top } 5 \text { (according to IF) } \\
\text { journals per fields of } \\
\text { anesthesiology and } \\
\text { gastroenterology } \\
\text { Editors: First } 5 \text { editorial board } \\
\text { members in each journal in } 2015 \\
\text { Years: Previous } 5 \text { years } \\
\text { Publications: All types }\end{array}$ & $\begin{array}{l}\text { Across journals, editors were more } \\
\text { likely to publish in their own journal } \\
\text { in comparison to any of the other } \\
\text { four journals. }\end{array}$ & $\begin{array}{l}\text { It is unclear to us when the } \\
\text { editors took the role. It could be } \\
\text { that these people became the } \\
\text { editors because they had } \\
\text { extensively published in the } \\
\text { journal before taking the } \\
\text { editorial role. } \\
\text { Some journals might expect } \\
\text { from their editors to write } \\
\text { editorials - unclear why they } \\
\text { were included. } \\
\text { Apparently, the data collection } \\
\text { lasted } 6 \text { months. }\end{array}$ \\
\hline $\begin{array}{l}\text { Hardin et al., } \\
2008\end{array}$ & $\begin{array}{l}\text { Journals: Editors of top } 5 \text { finance } \\
\text { journals (according to some } \\
\text { previous study); but publications } \\
\text { from these } 5 \text { and additional } 16 \\
\text { finance journals were analyzed. } \\
\text { Editors: Editorial board } \\
\text { members ( } \mathrm{N}=167 \text { ) from first } \\
\text { issue of years } 2000 \text { and } 2005 . \\
\text { Years: } 1990-2004 \\
\text { Publications: All type of articles } \\
\text { The purpose of study: editors' } \\
\text { research productivity, the focus } \\
\text { was not solely on self-publishing }\end{array}$ & $\begin{array}{l}\text { For one of the journals, the authors } \\
\text { wrote: "For Journal of Financial and } \\
\text { Quantitative Analysis, only } 59.6 \% \text { of } \\
\text { its same board members have at } \\
\text { least one appearance in the journal." } \\
\text { For the other journal, Financial } \\
\text { Management, the rate was } 50 \% \text {. } \\
\text { The authors write "In short, as was } \\
\text { generally found with the other } \\
\text { journals, editorial board members do } \\
\text { publish more in the journals on which } \\
\text { they serve as an editorial board } \\
\text { member when compared to other } \\
\text { board members." }\end{array}$ & $\begin{array}{l}\text { The main output was how often } \\
\text { EBMs from top } 5 \text { finance } \\
\text { journals publish in top } 21 \\
\text { finance journals. We were not } \\
\text { able to extract more info about } \\
\text { self-publishing than noted in our } \\
\text { results column. } \\
\text { Furthermore, editors were } \\
\text { selected by using the first issue } \\
\text { of the journals for the years } \\
2000 \text { and } 2005 \text { - while the } \\
\text { publications were from } 1990- \\
2004, \text { which makes it impossible } \\
\text { to draw any conclusions } \\
\text { regarding our aims. }\end{array}$ \\
\hline $\begin{array}{l}\text { Luty et al., } \\
2009\end{array}$ & $\begin{array}{l}\text { Journals: } 20 \text { ( } 4 \text { per } 5 \text { medical } \\
\text { subspecialties). } \\
\text { Editors: Members of the } \\
\text { editorial board (or editorial } \\
\text { advisory board) } \\
\text { Year: } 2006 \\
\text { Publications: Research } \\
\text { publications ( } N=4460)\end{array}$ & $\begin{array}{l}7.7 \% \text { of the publications were } \\
\text { authored by the journal's own } \\
\text { editorial board. } \\
2.8 \% \text { of the publications were } \\
\text { authored by "one of the three rival } \\
\text { journals' editorial boards within the } \\
\text { specialty." } \\
\text { "There was a statistically significant }\end{array}$ & $\begin{array}{l}\text { Because "each of the journals } \\
\text { had similar impact factors within } \\
\text { their field" the authors pointed } \\
\text { out that this "raises the } \\
\text { possibility that editorial } \\
\text { procedures are selectively } \\
\text { biased in favor of members of } \\
\text { their own editorial board." }\end{array}$ \\
\hline
\end{tabular}




\begin{tabular}{|c|c|c|c|}
\hline & & $\begin{array}{l}\text { excess of publications from the } \\
\text { journal's own editorial board in } 14 \text { of } \\
\text { the } 20 \text { journals }(p<0.05) . "\end{array}$ & \\
\hline $\begin{array}{l}\text { Mani et al., } \\
2013\end{array}$ & $\begin{array}{l}\text { Journals: Five leading (according } \\
\text { to IF) urologic journals } \\
\text { Editors: } 65 \text { editorial board } \\
\text { members who were elected in } \\
2006 \\
\text { Years: } 2001-2010 \\
\text { Publications: all original reports } \\
\text { The comparison: pre-editorial } \\
\text { period (2001-2005) vs. editorial } \\
\text { period (2006-2010) }\end{array}$ & $\begin{array}{l}\text { Editors published in total } 1800 \\
\text { articles during their pre-editorial } \\
\text { period and } 2845 \text { during the editorial } \\
\text { period; however, the proportion of } \\
\text { publications in their own journal did } \\
\text { not differ between periods. } \\
\text { An analysis on a journal level showed } \\
\text { that in } 3 \text { journals there were no } \\
\text { changes in the rate of self- } \\
\text { publications; in one there was an } \\
\text { increase (from } 20 \% \text { to } 36 \% \text { ) and in } \\
\text { one decrease (from } 80 \% \text { to } 30 \% \text { ). } \\
\text { The only journal showing a significant } \\
\text { increase in self-publications had an } \\
\text { increase in the impact factor from } 2.3 \\
\text { in } 2001 \text { to } 8.8 \text { in } 2010 \text {. }\end{array}$ & $\begin{array}{l}\text { The authors have discussed the } \\
\text { possibility that self-publishing in } \\
\text { a journal with high IF might be } \\
\text { tempting for editors. Illegitimate } \\
\text { impact factor boosting has also } \\
\text { been discussed. } \\
\text { The editorial boards for all } \\
\text { journals were changed in } 2006 \\
\text { providing a unique opportunity } \\
\text { for before vs. after comparison. }\end{array}$ \\
\hline $\begin{array}{l}\text { Mazov et al., } \\
2018\end{array}$ & $\begin{array}{l}\text { Journals: } 19 \text { top Russian } \\
\text { geological journals } \\
\text { Editors: Editors-in-chief, deputy } \\
\text { editors-in-chief, associate } \\
\text { editors, managing editors, and } \\
\text { secretaries of the editorial } \\
\text { board/executive secretaries } \\
\text { (N=434); advisory board } \\
\text { members were excluded } \\
\text { Years: "A 3-year period from } \\
2012 \text { to 2015" } \\
\text { Publications: type unclear }\end{array}$ & $\begin{array}{l}\text { Across journals, editors published } \\
10-29 \% \text { of their own papers in their } \\
\text { own journal, making } 12 / 19 \text { of } \\
\text { journals the first choice where they } \\
\text { publish. }\end{array}$ & $\begin{array}{l}\text { Advisory boards members were } \\
\text { excluded because "they are not } \\
\text { mandatory and do not exist in all } \\
\text { journals. In addition, this body is } \\
\text { advisory in nature and does not } \\
\text { play a decisive role in editorial } \\
\text { policy making." } \\
\text { Out of } 434 \text { people, " } 27 \text { people } \\
\text { are members of the editorial } \\
\text { boards of two journals and } 5 \\
\text { work for three journals." } \\
\text { Not clear what kind of } \\
\text { publications were included, e.g. } \\
\text { whether editorials were } \\
\text { excluded. }\end{array}$ \\
\hline $\begin{array}{l}\text { Reaee-Zavareh } \\
\& \text { Karimi-Sari, } \\
2020\end{array}$ & $\begin{array}{l}\text { Journals: "All Iranian medical } \\
\text { journals located in the Science } \\
\text { Citation Index Expanded (SCIE)" } \\
\text { Editors: "Chairperson, editor-in- } \\
\text { chief (EIC), or director in charge } \\
\text { of each included journal" } \\
\text { Years: Period 1: } 2015-2019 ; \\
\text { Period 2: all years in the } \\
\text { database until end of } 2019 \\
\text { Publications: articles and } \\
\text { reviews }\end{array}$ & $\begin{array}{l}\text { The median number of publications } \\
\text { in one's own journal was " } 17.72 \\
\text { ( } 51.31-30.55 \text { ) and } 19.05(2.63-36.33 \text { ) } \\
\text { until the end of } 2019 \text { and in } 2015- \\
2019 \text { respectively." } \\
\text { "On average, Iranian editors have } \\
\text { published } 18.90 \% \text { (standard deviation } \\
\text { [SD] = 15.03) and } 24.98 \% \text { (SD = 27.45) } \\
\text { of their papers in their own journals } \\
\text { until the end of } 2019 \text { and in } 2015- \\
2019 \text { respectively." }\end{array}$ & $\begin{array}{l}\text { The authors "did not consider } \\
\text { the period that a researcher had } \\
\text { been a journal editor," which } \\
\text { makes it almost impossible to } \\
\text { interpret this study. }\end{array}$ \\
\hline $\begin{array}{l}\text { Rosenblum et } \\
\text { al., } 2020\end{array}$ & $\begin{array}{l}\text { Journals: } 13 \text { generalist journals } \\
\text { in public administration } \\
\text { Editors: "All editors (including } \\
\text { editors-in-chief and co-editors)" } \\
\text { Years: } 1997-2016 \\
\text { Publications: Empirical articles } \\
\text { categorized before, during, and } \\
\text { after editorship }\end{array}$ & $\begin{array}{l}193 \text { observations among } 185 \text { editors } \\
\text { (some editors had roles at more than } \\
\text { one journal). } \\
\text { Self-publishing frequency was related } \\
\text { to the author's overall productivity } \\
\text { and the length of editorial service. } \\
\text { "The journals with the highest rates } \\
\text { of self-publishing are among those } \\
\text { with the highest impact factors." } \\
80 / 193 \text { editors self-published and } 9 \\
\text { of them more than } 5 \text { times. }\end{array}$ & $\begin{array}{l}\text { The authors concluded that self- } \\
\text { publishing is not a universal } \\
\text { problem, it is "more of a product } \\
\text { of certain journals and } \\
\text { individuals." } \\
\text { The authors noted that the final } \\
\text { publication date was used which } \\
\text { might have led to } \\
\text { misclassification in some cases } \\
\text { because articles were possible in } \\
\text { review before an editor took the }\end{array}$ \\
\hline
\end{tabular}




\begin{tabular}{|c|c|c|c|}
\hline & & & role. \\
\hline $\begin{array}{l}\text { Rösing et al., } \\
2014\end{array}$ & $\begin{array}{l}\text { Journals: Top ten (IF) journals } \\
\text { under “Dentistry, Oral Surgery \& } \\
\text { Medicine" subject category } \\
\text { Editors: editorial board } \\
\text { members } \\
\text { Years: } 2010-2012 \\
\text { Publications: Original research } \\
\text { reports }\end{array}$ & $\begin{array}{l}\text { The proportion of articles published } \\
\text { by editors in their own journal } \\
\text { ranged from } 3.8 \% \text { to } 50.3 \% \text { across } \\
\text { journals. Only two journals had a rate } \\
\text { below } 10 \% \text {. } \\
\text { The number of self-publications was } \\
\text { positively related to the journal's IF, } \\
\text { number of editorial board members, } \\
\text { and total number of articles } \\
\text { published in a journal. }\end{array}$ & $\begin{array}{l}\text { "Each published issue and article } \\
\text { was evaluated manually by one } \\
\text { of the authors." } \\
\text { The editorial board members list } \\
\text { from } 2013 \text { was used for all years. }\end{array}$ \\
\hline $\begin{array}{l}\text { Sen-Crowe et } \\
\text { al., } 2020\end{array}$ & $\begin{array}{l}\text { Journals: } 10 \text { journals randomly } \\
\text { selected from } 200 \text { peer reviewed } \\
\text { surgical journals with the highest } \\
\text { number of publications } \\
\text { Editors: Editorial Board Member } \\
\text { (EBM; } N=80 \text { ) or Associate Editor } \\
(A E ; N=721) . \\
\text { Years: } 2016-2019 \\
\text { Publications: "Peer-reviewed" }\end{array}$ & $\begin{array}{l}\text { For most journals and years, there } \\
\text { was an association between the } \\
\text { editors' overall productivity and the } \\
\text { number of their self-published } \\
\text { articles. } \\
\text { The proportion of self-publishing for } \\
\text { editors (\# of articles in own } \\
\text { journal/total \# of articles editor } \\
\text { published) varied from } 2.3 \% \text { to } 27.8 \% \\
\text { across journals. } \\
\text { The only journal with zero significant } \\
\text { association "adheres to a double- } \\
\text { blind review process". }\end{array}$ & $\begin{array}{l}\text { Editors were identified on the } \\
\text { journal's website at the time of } \\
\text { data collection. } \\
\text { The authors discussed the } \\
\text { potential of the double-blind } \\
\text { review process in reducing the } \\
\text { bias. } \\
\text { The main discussion in the paper } \\
\text { is around the association } \\
\text { between the editors' total } \\
\text { productivity and the number of } \\
\text { self-published articles; however, } \\
\text { this is of marginal interest if the } \\
\text { actual ratio is low. }\end{array}$ \\
\hline $\begin{array}{l}\text { Shamsi- } \\
\text { Gooshki et al., } \\
2020\end{array}$ & $\begin{array}{l}\text { Journals: Iranian scientific } \\
\text { journals approved by the } \\
\text { Ministry of Health and Medical } \\
\text { Education (N=408) } \\
\text { Years: first issue in year } 2018 \\
\text { Editors: only EiCs? } \\
\text { Publications: letters to the } \\
\text { editor, editorials, corrections } \\
\text { and abstracts were excluded } \\
\text { The purpose of study: to analyze } \\
\text { articles for various "general and } \\
\text { specific indicators related to } \\
\text { ethics in publishing research } \\
\text { articles"; self-publishing was one } \\
\text { of these indicators }\end{array}$ & $\begin{array}{l}6.6 \% \text { of articles were authored by } \\
\text { editors. } \\
\text { The proportion was lower for } \\
\text { Persian-language journals than in } \\
\text { English-language journals. }\end{array}$ & $\begin{array}{l}\text { Unclear whether only EiCs were } \\
\text { included - the authors write in } \\
\text { discussion: "Although this cutoff } \\
\text { also includes editorial board } \\
\text { members who have not been } \\
\text { investigated in our research..." } \\
\text { The authors note that according } \\
\text { to the National Guidelines for } \\
\text { Publication Ethics "journal } \\
\text { editors and officials are allowed } \\
\text { up to } 20 \% \text { authorship in their } \\
\text { journal articles." }\end{array}$ \\
\hline Walters, 2015 & $\begin{array}{l}\text { Journals: "30 well-known library } \\
\text { and information science } \\
\text { journals" - selected using } \\
\text { several criteria } \\
\text { Editors: Board members who } \\
\text { served at any time from Jan } \\
2007 \text { through Dec } 2012 \\
\text { ( } \mathrm{N}=1079) \\
\text { Years: } 2007-2012 \\
\text { Publications: All peer-reviewed } \\
\text { contributions: "research articles, } \\
\text { research notes, review articles, } \\
\text { and theoretical/conceptual } \\
\text { papers") }\end{array}$ & $\begin{array}{l}\text { Percentage of articles written by } \\
\text { board members varied from } 1 \% \text { to } \\
25 \% \text { across journals with the average } \\
\text { of } 8 \% \text {. Overall, } 17 \% \text { of all articles } \\
\text { were authored by board members. } \\
\text { "The correlation ( } r \text { ) between number } \\
\text { of board members and percentage of } \\
\text { articles written by board members is } \\
0.44 . \text {. } \\
\text { By using harmonic weighting and } \\
\text { standardization procedure (editors' } \\
\text { publishing in own journal/their total } \\
\text { publications and other authors' } \\
\text { publications in the journal/their total } \\
\text { publications), the authors reported } \\
\text { that "36\% of the } 1079 \text { board member } \\
\text { authors have actual values higher }\end{array}$ & $\begin{array}{l}\text { "Harmonic weighting was used } \\
\text { to assign credit for coauthored } \\
\text { articles" - this was done based } \\
\text { on the number of authors and } \\
\text { the author's place in the byline. } \\
\text { One of the most advanced } \\
\text { methodological approaches; } \\
\text { however, it is unclear when each } \\
\text { editor took their role and for } \\
\text { how long they served during the } \\
\text { six-year period. }\end{array}$ \\
\hline
\end{tabular}




\begin{tabular}{|c|c|c|c|}
\hline & & $\begin{array}{l}\text { than their expected values; the rest } \\
\text { are especially unlikely to publish in } \\
\text { their own journals." }\end{array}$ & \\
\hline $\begin{array}{l}\text { Youk \& Park, } \\
2019\end{array}$ & $\begin{array}{l}\text { Journals: } 17 \text { journals published } \\
\text { by US National (NCA) and the } \\
\text { International Communication } \\
\text { Association (ICA) } \\
\text { Editors: Editors and editorial } \\
\text { board members ( } 1063 \\
\text { individuals; } 261 \text { of them had } \\
\text { multiple roles leading to the } \\
\text { total number of } 1287 \\
\text { observations). } \\
\text { Years: } 2007-2016 \\
\text { Publications: empirical vs. non- } \\
\text { empirical }\end{array}$ & $\begin{array}{l}\text { During } 10 \text { years, an editor/EBM had } \\
\text { on average } 1.10 \text { (SD = 1.94) } \\
\text { publications in own journal. } \\
\text { More than half of the editors/EBMs } \\
\text { have not published in their own } \\
\text { journal. } \\
\text { When self-published articles were } \\
\text { written alone, more papers than } \\
\text { expected were non-empirical and } \\
\text { fewer papers than expected were } \\
\text { empirical papers. For the co- } \\
\text { authored articles, the pattern was } \\
\text { reverse. }\end{array}$ & $\begin{array}{l}\text { The authors did not account for } \\
\text { when the editors/EBMs took } \\
\text { their positions - ten years is a } \\
\text { long period. However, this is not } \\
\text { a problem for self-publishing } \\
\text { because the overall rate was } \\
\text { low. } \\
\text { On the other hand, it raises the } \\
\text { question about why one } \\
\text { becomes the editor/EBM in a } \\
\text { journal where they had rarely } \\
\text { published before they took the } \\
\text { role. } \\
\text { Journals had large number of } \\
\text { editors, on average } 76 \text {. } \\
\text { It is expected that non-research } \\
\text { papers (e.g., editorials) are more } \\
\text { often written alone. }\end{array}$ \\
\hline Zdenek, 2018 & $\begin{array}{l}\text { Journals: Six Czech and Slovak } \\
\text { Journals indexed in the Journal } \\
\text { Citation Report, categories: } \\
\text { Business; Business, Finance; and } \\
\text { Economics - also } 6 \text { randomly } \\
\text { selected journals with similar IF } \\
\text { Years: } 2012-2015 \\
\text { Editors: editors, editors in chief, } \\
\text { executive editors, consulting } \\
\text { editors, co-editors, associate } \\
\text { editors, members of } \\
\text { executiveand advisory board and } \\
\text { other editorial board members } \\
\text { without specified function. } \\
\text { Publications: research articles }\end{array}$ & $\begin{array}{l}\text { The average share of articles, where } \\
\text { an editorial board member is the } \\
\text { author or co-author, ranges from } \\
0.6 \% \text { to } 17.5 \% \text { across journals. In } \\
\text { some years for some journals, this } \\
\text { share reaches } 25 \% \text {. } \\
\text { Across journals, editors publish from } \\
8 \% \text { to } 71 \% \text { of their articles in their } \\
\text { own journal. } \\
\text { Across journals, the proportion of } \\
\text { editors publishing only in own journal } \\
\text { ranges from zero to } 86 \% \text {. }\end{array}$ & $\begin{array}{l}\text { "The composition of editorial } \\
\text { boards was taken from the first } \\
\text { issue of the year." } \\
\text { If an EBM published an article in } \\
\text { the journal before becoming a } \\
\text { member, this article was not } \\
\text { counted as in their own journal. }\end{array}$ \\
\hline $\begin{array}{l}\text { Zdenek \& } \\
\text { Lososova, } \\
2018\end{array}$ & $\begin{array}{l}\text { Journals: Ten out of } 17 \text { Journals } \\
\text { indexed in the Journal Citation } \\
\text { Report (category: Agricultural } \\
\text { Economics and Policy) were } \\
\text { randomly selected } \\
\text { Years: } 2012-2016 \\
\text { Editors: same as in Zdenek } \\
\text { (2018) } \\
\text { Publications: research articles }\end{array}$ & $\begin{array}{l}\text { The average share of articles, where } \\
\text { an editorial board member is the } \\
\text { author or co-author, ranges from } \\
1.3 \% \text { to } 21.1 \% \text { across journals, with } \\
\text { an overall average of } 7.7 \% \text {. } \\
3 \text { out of } 10 \text { journals have an average } \\
\text { rate above } 10 \% \text {. } \\
\text { The average share of EBMs } \\
\text { publishing in their own journal is } \\
14.6 \% \text {, with the range of } 6-22 \% \text {. } \\
\text { Across journals, editors publish from } \\
3.3 \% \text { to } 43.6 \% \text { of their articles in their } \\
\text { own journal, with an overall average } \\
\text { of } 10.1 \% \text {. } \\
\text { Across journals, the share of EBMs } \\
\text { who do not publish at all (according } \\
\text { to Web of Science) or publish only in } \\
\text { their own journal ranges from } 6.1 \% \\
\text { to } 72.7 \% \text {. }\end{array}$ & $\begin{array}{l}\text { "The composition of editorial } \\
\text { boards was taken from the first } \\
\text { issue of the year." }\end{array}$ \\
\hline
\end{tabular}




\section{APPENDIX 1: SEARCH STRATEGY}

\section{Scopus}

( TITLE-ABS-KEY ( "editorial board member*" OR "editorial board*" OR "journal editor*" OR "editor* publish*" ) ) AND ( TITLE-ABS-KEY ("own journal*" OR "self-publish*" OR "preferential publication*" OR "conflict of interest*" ))

Hits: 364

\section{Medline and Psyclnfo}

Ovid MEDLINE(R) and Epub Ahead of Print, In-Process \& Other Non-Indexed Citations, Daily and Versions(R) 1946 to December 29, 2020, [Database Field Guide] APA PsycInfo 1806 to December Week 3 2020

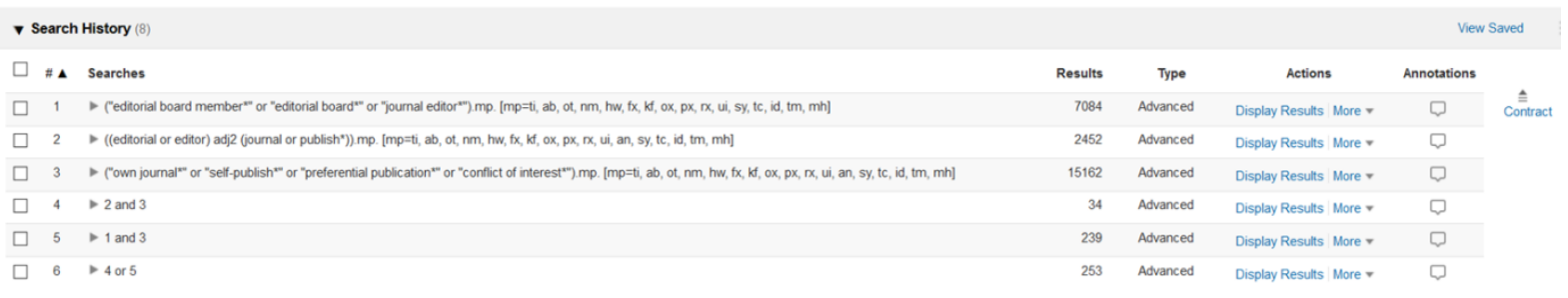

Hits: 253

\section{Web of Science}

TOPIC: ("editorial board member*" OR "editorial board*" OR "journal editor*" OR "editor* publish*") AND TOPIC: ("own journal*" OR "self-publish*" OR "preferential publication*" OR "conflict of interest*")

Hits: 127

\section{SUMMARY}

Scopus: 364 hits

Ovid (Medline \& Psyclnfo): 253 hits

Web of Science: 127 hits

Own library: 18 articles (6 not identified in the above searches)

All together $364+253+127+6$ additional from own library

744+6->750 (see attached Prisma flow diagram) 
Records identified through database searching

$$
(n=744)
$$

Additional records identified through other sources

$(n=6)$

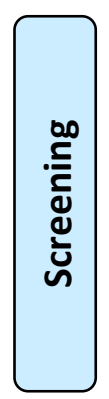

Records after 346 duplicates removed

$(n=404)$
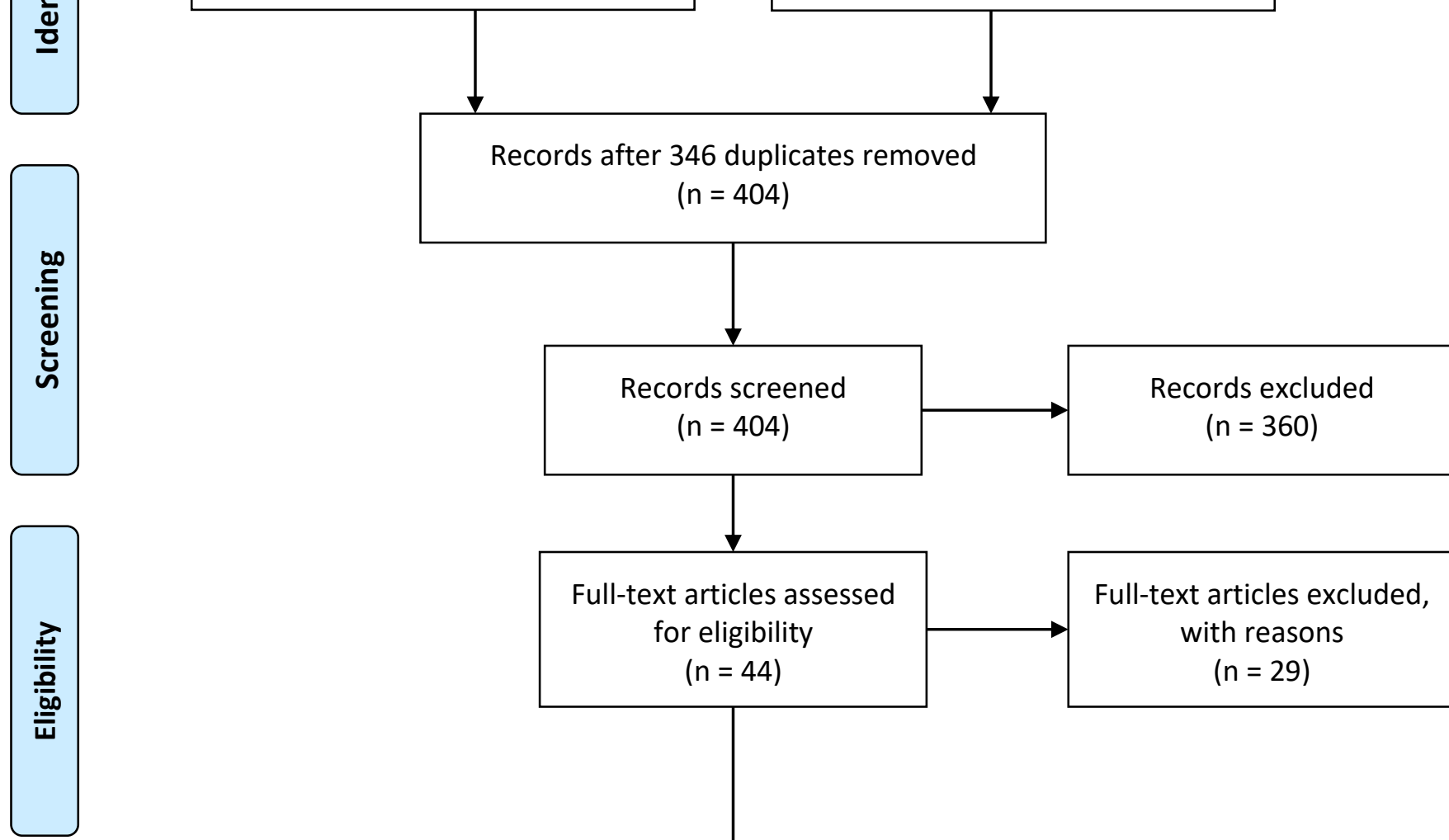

욤

Studies included in qualitative synthesis $(n=15)$ 